\title{
Length-Weight Relationship and Condition Factor of Mudskipper Boleophthalmus pectinirostris from Maro Estuary, Merauke Regency, Papua
}

\author{
Sunarni ${ }^{*}$, Edy H.P. Melmambessy ${ }^{1}$, Norce Mote' ${ }^{1}$ Rahmatia', Baigo Hamuna ${ }^{2}$ \\ 1 Department of Management of Aquatic Resources, Department of Agriculture, Universityof Musamus, \\ Kamizaun Street, Mopah Lama, Merauke Regency 99600, Papua Province, Indonesia \\ 2 Department of Marine Science and Fisheries, Cenderawasih University, Kamp Wolker Street, Yabansai, \\ Jayapura City 99351, Papua Province, Indonesia \\ * Corresponding author's e-mail: sunarni@unmus.ac.id
}

\begin{abstract}
This study aimed at analyzing the length-weight relationship and the condition factors of Boleophthalmus pectinirostris originating from the Maro estuary, Merauke Regency, Papua Province, Indonesia. This study was conducted for three months, starting from July to September 2018. This study used a purposive sampling method. The sampling of B. pectinirostris was carried out at two stations by using traps and capturing manually. 80 fish of B. pectinirostris were caught during the study. The length size of males 6.5 to $17.5 \mathrm{~cm}$ and weight 1.7 to $44.0 \mathrm{~g}$, while the length of females 9.0 to $22.0 \mathrm{~cm}$ and weight 5.4 to $91.4 \mathrm{~g}$. The results showed that the length-weight relationship of B. pectinirostris male reached $\mathrm{W}=0.0112 \mathrm{~L}^{2.8562}$ and $\mathrm{W}=0.0099 \mathrm{~L}^{2.8885}$, while females $\mathrm{W}=0.0062 \mathrm{~L}^{3.0907}$ and $\mathrm{W}=0.0052 \mathrm{~L}^{3.1211}$. The length and weight relationship of $B$. pectinirostris showed negative allometric for male $(b<3)$ and positive allometric for female $(b>3)$. The condition factor value of $B$. pectinirostris for males and females ranged from 0.837 to 2.266 , and 0.689 to 1.259 , respectively.
\end{abstract}

Keywords: Boleophthalmus pectinirostris, length-weight relationship, condition factor, positive allometric, negative allometric, Maro estuary, Merauke-Papua

\section{INTRODUCTION}

The Mudskipper is included in the Family Gobiidae and Subfamily Oxudercinae [Murdy, 1989]. Mudskipper is one type of fish that is adapted to two different habitats, i.e. land and waters. Generally, Mudskipper habitats usually cover the estuary region which is part of the sea, shallow sea, and subtidal region in tidal areas [Jaafar et al., 2009; Tang et al., 2009; Mahadevan and Ravi, 2015]. In addition, Mudskipper relies heavily on the presence of mangrove forests and occupy a position as primary and secondary consumers in the food chain in the coastal ecosystems [Tang et al., 2009; Polgar and Lim, 2011; Elviana and Sunarni, 2018].

The various benefits of Mudskipper fish have been used for various purposes. The Mudskipper is consumed as a traditional medicine to cure diarrheal diseases for children in India and can be used as a drug to strengthen fetuses in China and Japan [Ravi and Rajagopal, 2009]. Mudskipper fish is believed to be able to increase energy so it is often consumed for fetal health by pregnant women [Purwaningsih et al., 2013]. Meanwhile, the utilization of Mudskipper in Indonesia is still very small, but it is very potential to be traded, both as consumption fish and as raw material for animal and fish food [Muhtadi et al., 2016].

The potential of Mudskipper at the Maro estuary, Merauke Regency is very high. There are 6 Mudskipper species found in the mouth of the Maro estuary in Merauke Regency, Papua Province, Indonesia, including Boleophthalmus boddarti, B. pectinirostris, Oxuderces dentatus, Periophthalmus argentilineaus, P. takita, and 
Scartelaos histophorus [Maturbongs et al., 2017]. However, there is no information and study regarding the growth patterns and factor conditions of Mudskipper fish in Merauke Regency, Papua Province, Indonesia.

The pattern of growth and conditions factor of fish can be identified by measuring the length and weight of fish [Shalloof and El-Far, 2017; Lanzoni et al., 2018; Karna et al., 2018; Philips, 2019; Amin and Sabrah, 2019]. Several studies were conducted to examine the relationship between the length and weight of Mudskipper fish. In Indonesia, the studies the length-weight relationship of $B$. pectinirostris have not been conducted. The information on the length-weight relationship of fish is highly important in the framework of fisheries management and fish stock assessment. Therefore, this study aimed at examining the length-weight relationship and condition factor of $B$. pectinirostris found in the Maro estuary, Merauke Regency, Papua Province, Indonesia.

\section{MATERIALS AND METHODS}

A sampling of B. pectinirostris at two research stations in the Maro estuary, Merauke Regency, Papua Province, Indonesia. The station I is located at coordinates $8^{\circ} 2^{\prime} 36.05^{\prime \prime} \mathrm{S} 140^{\circ} 22^{\prime} 35.23^{\prime \prime} \mathrm{E}$ and station II at $8^{\circ} 28^{\prime} 32.61^{\prime \prime} \mathrm{S} 140^{\circ} 22^{\prime} 30.97^{\prime \prime}$ E. The sampling was done six times from July to September 2018.

The sampling method used was purposive sampling. The sampling of $B$. pectinirostris was carried out at low tide using two methods. The first method, involved a trap device made of ram wire. The traps were installed in the nest hiding B. pectinirostris so that the fish around the nest could be trapped into the trap. The second method, fishing was done manually and assisted by local people who have the expertise at capturing B. pectinirostris. Furthermore, B. pectinirostris samples were analyzed at the Laboratory of Aquatic Resource Management, Faculty of Agriculture-Musamus University to identifying the $B$. pectinirostris based on fish sex and measurements of the fish length and weight.

The analysis of the length-weight relationship of $B$. pectinirostris was carried out separately between males and females. The analysis of the length-weight relationship was carried out to determine the growth pattern of $B$. pectinirostris based on the following equation [Lagler, 1961; Ricker, 1975]:

$$
W=a L^{b}
$$

where: $L$ is the total length, $W$ is the total weight, $a$ and $b$ values are constant numbers.

One of the important attributes of fish growth pattern is the Fulton $(\mathrm{K})$ condition Factor. The condition factor indicates the state of physical capacity for fish survival and reproduction [Effendie, 1997]. The coefficient of the Fulton (K) condition factor was determined by means of the following formula [Okgerman, 2005]:

$$
K=W L^{-3} \times 100
$$

where: $K$ is the condition factor,

$W$ is the weight $(\mathrm{g})$,

$L$ is the total length $(\mathrm{mm})$ and -3 is the coefficient.

The condition factor values in the range of $0-2$ indicate that the body of the fish is less flat and the range of 3-4 indicates the body of the fish is slightly flat [Effendie, 1997].

\section{RESULTS AND DISCUSSION}

\section{Length-Weight Relationship of B. pectinirostris}

During the study, captured B. pectinirostris included 80 fish consisting of 37 fish (16 males and 21 females) at the station I and 43 fish (20 males and 23 females) at station II (Table 1). Overall, the length size of males $B$. pectinirostris range from 6.5 to $17.5 \mathrm{~cm}$ and females range from 9.0 to $22.0 \mathrm{~cm}$. The weight size of males $B$. pectinirostris ranges from 1.7 to $44.0 \mathrm{~g}$, while females range from 5.4 to $91.4 \mathrm{~g}$. The differences in fish length can be caused by the differences in the location of fish sampling. One same fish species can reach different maximum lengths depending on where the species is located.

The length-weight relationship in fish is of great importance in fishery assessments [Haimovic and Velasco, 2000]. Table 1 presents the results of the analysis pertaining to fish length, weight, and parameters of the fish-length relationship B. pectinirostris. On the basis of the results in Table 1, the length-weight relationship of male $B$. pectinirostris at the station I and station II is $\mathrm{W}=0.0112 \mathrm{~L}^{2.8562}$ and $\mathrm{W}=0.0099 \mathrm{~L}^{2.8885}$, respectively. The $b$ values $(\mathrm{b}=2.8562$ and $\mathrm{b}=2.8885)$ reached $b<3$, whicc means that the growth pattern 
Table 1. Fish length, weight, and length-weight relationship parameters of $B$. pectinirostris

\begin{tabular}{|c|l|c|c|c|c|c|c|c|c|}
\hline \multirow{2}{*}{ Station } & \multirow{2}{*}{ Sex } & \multirow{2}{*}{$\begin{array}{c}\text { Number } \\
\text { of fish }\end{array}$} & \multicolumn{2}{|c|}{ Length $(\mathrm{cm})$} & \multicolumn{2}{c|}{ Weight $(\mathrm{g})$} & \multicolumn{3}{c|}{$\mathrm{L}-\mathrm{W}$ relationship $\left(\mathrm{W}=\mathrm{aL}^{\mathrm{b}}\right)$} \\
\cline { 6 - 11 } & & & Min & Max & Min & Max & $\mathrm{a}$ & $\mathrm{b}$ & $\mathrm{R}^{2}$ \\
\hline \multirow{2}{*}{$\mathrm{I}$} & Male & 16 & 9.3 & 17.5 & 6.3 & 44.0 & 0.0112 & 2.8562 & 0.9640 \\
\cline { 2 - 12 } & Female & 21 & 9.0 & 17.5 & 5.4 & 52.1 & 0.0062 & 3.0907 & 0.9784 \\
\hline \multirow{2}{*}{ II } & Male & 20 & 6.5 & 16.4 & 1.7 & 29.1 & 0.0099 & 2.8885 & 0.9322 \\
\cline { 2 - 11 } & Female & 23 & 9.5 & 22.0 & 6.0 & 91.4 & 0.0052 & 3.1211 & 0.9796 \\
\hline
\end{tabular}

of male $B$. pectinirostris is negative allometric. In turn, the length-weight relationship of female $B$. pectinirostris at the station I and station II was $\mathrm{W}=0.0062 \mathrm{~L}^{3.0907}$ and $\mathrm{W}=0.0052 \mathrm{~L}^{3.1211}$, respectively. The $b$ values $(\mathrm{b}=3.0907$ and $\mathrm{b}=3.1211)$ of $b>3$ mean that the growth pattern of female $B$. pectinirostris is positive allometric. The results of this study show that the growth pattern of male $B$. pectinirostris is allometric negative, indicating that the energy obtained from the intake of fish nutrients tends to be used more for movement activities such as swimming, which causes the absorption of nutrients to reduce the fish weight. Conversely, the growth pattern of female $B$. pectinirostris is allometric positive which indicates the tendency of more silent fish so that there is a buildup of energy and this condition is used for the formation of new cells so that the fish body weight increases [Effendie, 1997].

The regression coefficient graph of the length-weight relationship of $B$. pectinirostris is presented in Figure 1 for station I and Figure 2 for station II. Overall, the results of this study show that the coefficient of determination $\left(\mathrm{R}^{2}\right)$ ranged between from 0.9322 to 0.9796 . It means that 93.2-97.9\% of fish weight increase can explain the condition of fish length, while the rest can be caused by other factors such as environmental factors and age. If the value of determination $\left(\mathrm{R}^{2}\right)$ is high, a close relationship between weight gain and increase in fish length is indicated, and vice versa. In this study, B. pectinirostris has a correlation value that approaches 1 which indicates the closer the relationship between the two variables (fish length and weight). On the basis of the coefficient of determination $\left(\mathrm{R}^{2}\right)$, the coefficient of correlation $(\mathrm{R})$ can be obtained, ranging from 0.9655 to 0.9897 , which indicates that there is a high correlation between the growth of the length and weight of $B$. pectinirostris.

The length-weight relationship and the growth pattern of $B$. pectinirostris obtained in this study are relatively similar to the results study by Yang et al. [2003] and Jeong et al. [2004]. The results study by Yang et al. [2003] obtained $b$ value are $b=2.588$ at a fish length of $5.0 \mathrm{~cm}$ to $12.0 \mathrm{~cm}$. In turn, in the results study by Jeong et al. [2004], the obtained b values for male B. pectinirostris (fish length $10.5 \mathrm{~cm}$ to $18.0 \mathrm{~cm}$ ) and female (fish length $11.0 \mathrm{~cm}$ to $19.0 \mathrm{~cm}$ ) were $\mathrm{b}=2.180$ and $\mathrm{b}=3.120$, respectively. According to Muchlisin [2010], the b value is influenced by the behavior of fish, for example, fish that move actively. Some of the results of research on the length-weight relationship of another Mudskipper types, such as the results study by Bidawi et al. [2017] which obtained the $b$ value for $P$. chrysospilos, $P$. gracilis, and B. boddarti were
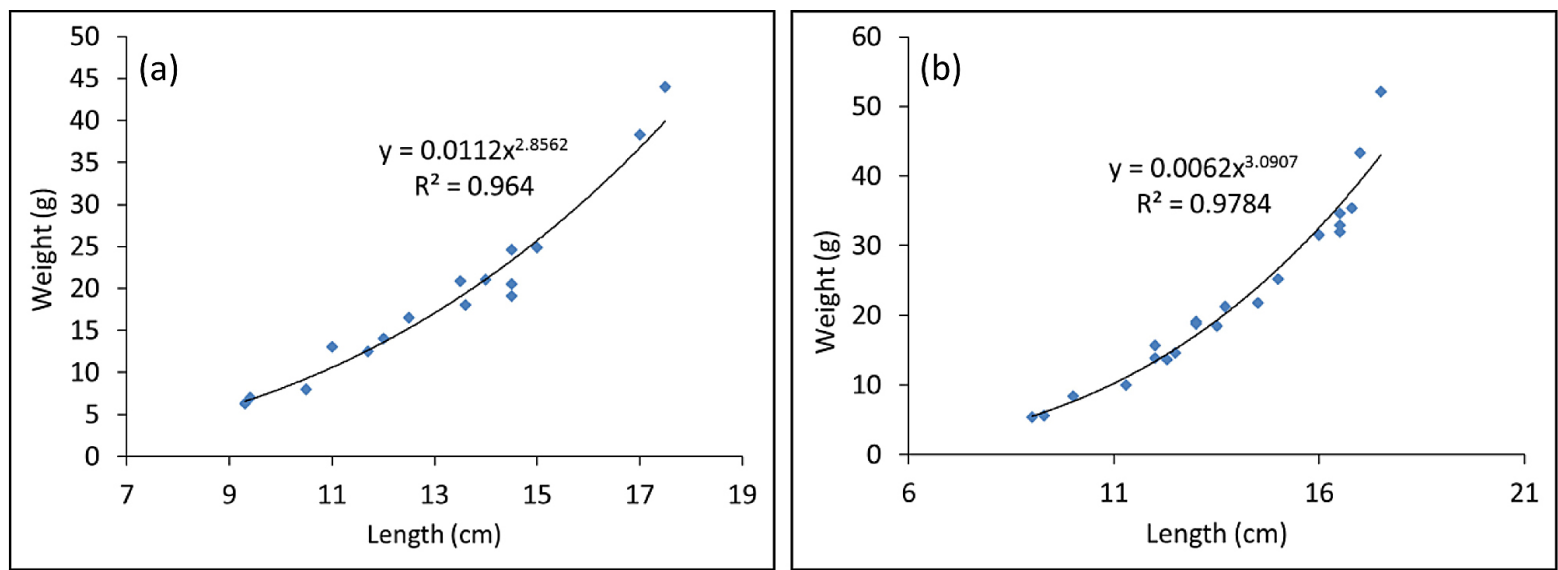

Figure 1. Graph of length-weight relations of B. pectinirostris at stasiun I (a) male and (b) female 

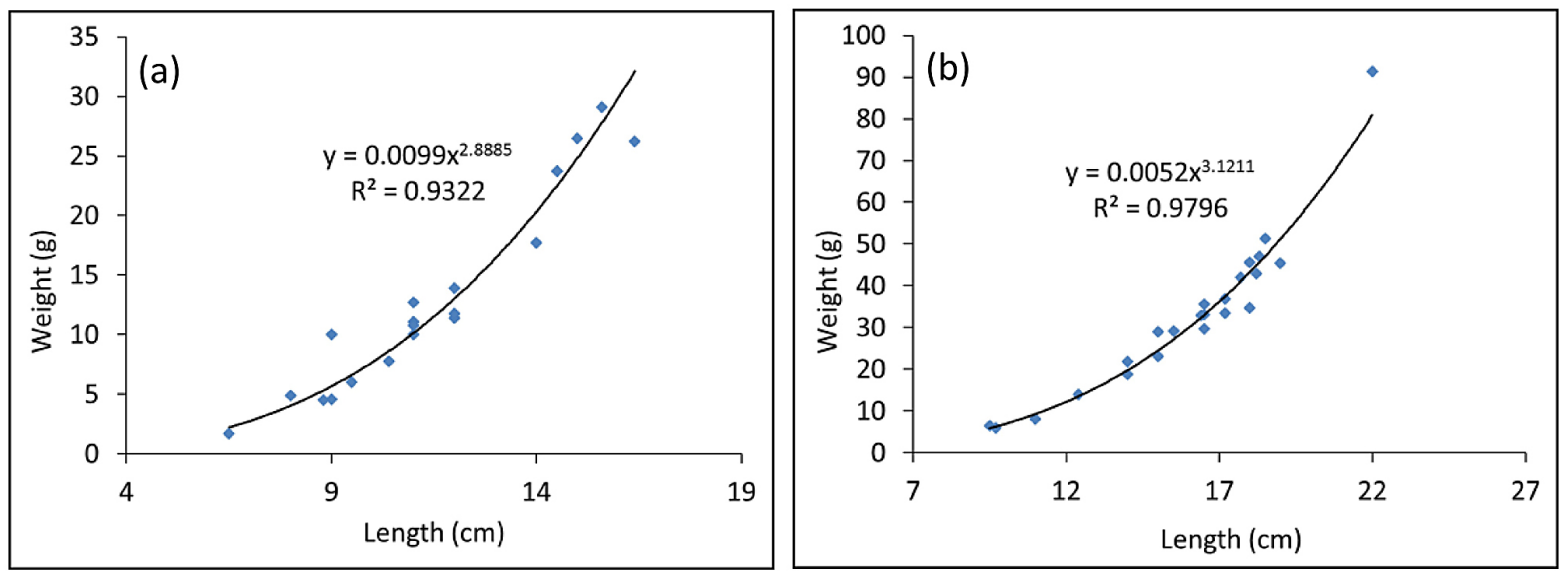

Figure 2. Graph of length-weight relations of B. pectinirostris at stasiun II (a) male and (b) female

$\mathrm{b}=2.953, \mathrm{~b}=2.275$, and $\mathrm{b}=2.7367$, respectively. The results of the study by Dinh [2017] showed the $\mathrm{b}$ values for $B$. boddarti male and female in the range $b=2.04$ to $b=3.22$, and $\mathrm{b}=2.57$ to $\mathrm{b}=3.31$, respectively. Furthermore, the results of the study by Mahadevan et al. [2017] reached the b values of $O$. dentatus and $S$. histophorus were $\mathrm{b}=2.718$, and $\mathrm{b}=2.689$, respectively.

The body length and weight of fish throughout its life cycle are very influential on the $b$ value (growth value) so that the factors that indirectly influence the body size of fish will affect the growth pattern [Suwarni, 2009]. There are several factors that influence fish growth, including offspring, reproduction, parasite age, and disease, while external factors include the amount and size of available food, temperature, dissolved oxygen, and water quality [Effendie, 1997]. The changes in the weight of fish can result from the changes in feed and energy allocation for growth and reproduction, which leads to different fish weight even though the length is the same [Meretsky et al., 2000].

\section{The Condition Factor of B. pectinirostris}

Condition factors are calculated to assess general fish health, productivity and physiological conditions of fish populations [Blackwell et al., 2000; Richter, 2007]. The factors of this condition reflect the morphological characteristics of the body, fat content and growth rate [Froese, 2006; Stevenson and Woods, 2006]. Table 2 presents the analysis results of the conditions factor of B. pectinirostris in the Maro estuary, Merauke Regency. The results in Table 2 indicate that the condition factor of male and female $B$. pectinirostris is different, ranging between 0.837 to 2.66 and 0.689 to 1.259 , respectively. The obtained value of the condition factor indicates that the body fish is less flat. The condition factor values of fish range from 0 to 2 indicate the body of the fish is less flat and the condition factor value of fish ranging from 3 to 4 shows the body of the fish is slightly flattened. Descriptively, it can be stated that the condition factor in the male individuals is relatively greater than in the female individuals. The difference in factor values of this condition is due to gender [Lorenzoni et al., 2015].

A condition factor is an important tool for the study of fish biology, mainly when the species lies at the base of the higher food web [Diaz et al., 2000]. The higher the value of the condition factor indicates a match between the fish and the environment. Generally, the range of condition factors of the female fish is higher than in the case of the male fish [Rahardjo and Simanjuntak, 2008]. However, the results of this study indicate that

Table 2. Factor condition of $B$. pectinirostris

\begin{tabular}{|c|l|c|c|c|c|}
\hline \multirow{2}{*}{ Station } & \multirow{2}{*}{ Sex } & \multirow{2}{*}{ Number of fish } & \multicolumn{3}{|c|}{ Condition factor (K) } \\
\cline { 4 - 6 } & & & Min & Max & Average \\
\hline \multirow{2}{*}{$I$} & Male & 16 & 0.837 & 1.245 & 1.015 \\
\cline { 2 - 6 } & Female & 21 & 0.964 & 1.259 & 1.709 \\
\hline \multirow{2}{*}{ II } & Male & 20 & 0.986 & 2.266 & 0.943 \\
\cline { 2 - 6 } & Female & 23 & 0.689 & 1.107 & \\
\hline
\end{tabular}


the condition factor of male $B$. pectinirostris is relatively higher than the female $B$. pectinirostris. This condition can be due to the possibility of females $B$. pectinirostris releasing their eggs and restoring their original shape so that the range of condition factors is low. Increasing of condition factors value of fish is relatively high when the gonads of fish are filled and reach their peak before spawning occurs. The conditions factor will differ depending on gender, season and location of capture, level of gonadal maturity, an abundance of food and environmental conditions of the waters [King, 1995]. The condition factors of fish can also be influenced by the number and density of predators [Anderson and Gutreuter, 1983; Murphy et al., 1991; Blackwell et al., 2000].

\section{CONCLUSION}

In this study, the differences in length-weight relations of male and female $B$. Pectinirostris were investigated. On the basis of the length-weight relationship of $B$. pectinirostris it was observed that the growth pattern of the male is negative allometric, while females are positively allometric, and the condition factor of the male is higher than the female. The differences in growth patterns and condition factors can be caused by various factors such as differences in fish length and weight, differences in food availability, breeding phase of female fish, level of fish movement, and other environmental conditions.

\section{REFERENCES}

1. Amin A.M., Sabrah M.M. 2019. Basic parameters for assessment and management of the ShortFinned Squid Illex coindetii (Verany, 1839) (Cephalopoda, Ommastrephidae) from the deep water off the Egyptian Mediterranean Sea. Egyptian Journal of Aquatic Biology and Fisheries, 23(1), 13-26.

2. Anderson R.O., Gutreuter S.J. 1983. Length, weight, and associated structural indices. [in:]: Fisheries Techniques. [eds.]: L. Nielsen, D. Johnson. American Fisheries Society, Bethesda, Maryland.

3. Bidawi B.Y., Destrita, Yunasfi. 2017. Lenghtweight relationships and condition factor of mudskipper (Family: Gobiidae) at the mangrove ecosystem of the Sembilan Island Village of Langkat Regency, North Sumatera. Depik, 6(3), 228-234. (in Indonesian)
4. Blackwell B.G., Brown M.L., Willis D.W. 2000. Relative weight (Wr) status and current use in fisheries assessment and management. Reviews in Fisheries Science, 8(1), 1-44.

5. Diaz L.S., Roa A., Garcia C.B., Acero A., Navas G. 2000. Length-weght relationship of demersal fishes from the upper continental slope off Columbia. NAGA, 23(3), 23-25.

6. Dinh Q.M. 2017. Morphometric, growth and condition factor variations of Boleophthalmus boddarti in the Mekong delta, Vietnam. Iranian Journal of Fisheries Sciences, 16(2), 822-831.

7. Effendie M.I. 1997. Fisheries biology. Yayasan Pustaka Nusatama, Yogyakarta. (in Indonesian)

8. Elviana S., Sunarni. 2018. The compositian and abudance of mudskipper species relationship with organic materials in estuary aquatic, Merauke Districts. Jurnal Agribisnis Perikanan, 11(2), 38-43. (in Indonesian)

9. Froese R. 2006. Cube law, condition factor and weight-length relationships: history, meta-analysis and recommendations. Journal of Applied Ichthyology, 22, 241-253.

10. Haimovic M., Velosco G. 2000. Length weight relationship of marine from southern Brazil. NAGA, 23(1), 14-16.

11. Jaafar Z., Perrig M., Chau L.M. 2009. Periophthalmus variabilis (Teleostei: Gobiidae: Oxudercinae), a valid species of mudskipper, and a re-diagnosis of Periophthalmus novemradiatus. Zoological Science, 26, 309-314.

12. Jeong S.J., Han K.H., Kim J.K., Sim D.S. 2004. Age and growth of the blue spot mudskipper (Boleophthalmus pectinirostris) in the mud flat of Southwestern Korea. J. Korean Fish. Soc. 37(1), 44-50.

13. Karna S.K., Katselis G.N., Jawad L.A. 2018. Length-weight relations of 24 fish species (Actinopterygii) from Hirakud Reservoir, Odisha State of India. Acta Ichthyologica et Piscatoria, 48(1), 83-86.

14. King M. 1995. Fisheries biology: Assessment and management. Blackwell Publishing, Oxford, UK.

15. Lagler K.F. 1961. Freshwater fishery biology. Second eds. WM.C. Brown Company, Dubuque, Lowa.

16. Lanzoni M., Aschonitis V., Milardi M., Castaldelli G., Fano E.A. 2018. A method to identify bimodal weight-length relations: Possible ontogenetic diet and/or metabolism shift effects in Anguilla anguilla (Actinopterygii: Anguilliformes: Anguillidae). Acta Ichthyologica et Piscatoria, 48(2), 163-171.

17. Lorenzoni M., Giannetto D., Carosi A., Dolciami R., Ghetti L., Pompei L. 2015. Age, growth and body condition of big-scale sand smelt Atherina boyeri Risso, 1810 inhabiting a freshwater environment: Lake Trasimeno (Italy). Knowledge and Management of Aquatic Ecosystems, 416(9), 1-13. 
18. Mahadevan G., Ravi V. 2015. Distribution of mudskippers in the mudflats of muthupet, Southeast coast of India. International Journal of Fisheries and Aquatic Studies, 3(2), 268-272.

19. Mahadevan G., Ravi V., Murugesan P. 2017. Length-weight relationship of two mudskippers (Gobiidae: Oxudercinae) Oxuderces dentatus (Eydoux \& Souleyet, 1850) and Scartelaos histophorus (Valenciennes, 1837) from Dhamara estuary, Odhisa, India. Journal of Applied Ichthyology, 33(6), 1258-1260.

20. Maturbongs R.M., Elviana S., Sunarni, deFretes D. 2017. Mudskipper (Gobiidae) diversity study on estuary of Maro river and mangrove area in Kembapi Beach, Merauke. Depik, 7(2), 177-186. (in Indonesian)

21. Meretsky V.J., Valdes R.A., Douglas M.E., Brouder M.J. Gorman O.T., Marsh P.C. 2000. Spatiotemporal variation in lenght-weigth relationship of endangered humpback chub: impications for conservation and management. Transaction of the Amerika Fisheries Society, 129, 419-428.

22. Muchlisin Z.A. 2010. Biodeversity of freshwater fishes in Aceh Province, Indonesia with emphasis on several biological aspects of the Depik (Resbora tawarensis) an endemic epecies in Lake Laut Tawar. Ph.D Thesis, Universiti Sains Malaysia, Panang.

23. Muhtadi A., Ramadhani S.F., Yunasfi. 2016. Identification and habitat type of mudskipper (Family: Gobiidae) at the Bali Beach, District of Batu Bara, North Sumatra Province. Biospecies, 9(2), 1-6. (in Indonesian)

24. Murdy E.O. 1989. Taxonomic revision and clodistic analysis of the Oxudercine Gobies (Gobidae oxudercinae). Records of the Australian museum supppl., 11, 1-93.

25. Murphy B.R., Brown M.L., Spinger T.A. 1991. The relative weight (Wr) index management; Status and needs. Fisheries, 16(2), 30-38.

26. Okgerman H. 2005. Seasonal variation of the length weight and condition factor of Rudd (Scardinius erythrophthalmus L) in Spanca Lake. International Journal of Zoological Research, 1(1), 6-10.

27. Philips A.E. 2019. Fishery biology of Terapon puta (Cuvier, 1829) from east Egyptian Mediterranean waters. Egyptian Journal of Aquatic Biology and
Fisheries, 22(1), 197-203.

28. Polgar G., Lim R. 2011. Mudskippers: Human use, ecotoxicology and biomonitoring of mangrove and other soft bottom intertidal ecosystems. Faculty of Science, University of Malaya Kuala Lumpur, Malaysia.

29. Purwaningsih S., Salamah E., Riviani. 2013. The changing of chemical composition, amino acids, and taurine content at glodok fish (Periopthalmodon schlosseri). Jurnal Pengolahan Hasil Perikanan Indonesia, 16(1), 12-21. (in Indonesian)

30. Rahardjo M.F., Simanjuntak C.P.H. 2008. Lengthweight relationship and condition factor of belanger's croaker, Johnius belangerii Cuvier (Pisces: Sciaenidae) in Mayangan coastal waters, West Java. Jurnal Ilmu-ilmu Perairan dan Perikanan Indonesia, 15(2), 135-140. (in Indonesian)

31. Ravi V., Rajagopal S. 2009. Mudskipper. Centre of Advanced Study in Marine Biology, Annamalai University.

32. Richter T.J. 2007. Development and evaluation of standard weight equations for bridgelip sucker and largescale suckers. North American Journal of Fisheries Management, 27, 936-939.

33. Shalloof K.A.Sh., El-Far A.M. 2017. Lengthweight relationship and condition factor of some fishes from the river Nile in Egypt with special reference to four tilapia species. Egyptian Journal of Aquatic Biology and Fisheries, 21(2), 33-46.

34. Stevenson R.D., Woods W. A. 2006. Condition indices for conservation: new uses for evolving tools. Integrative and Comparative Biology, 46, 1169-1190.

35. Suwarni. 2009. Long-weight relationship and conditions of Acanthurus mata (Cuvier, 1829) captured in coastal waters around Mattiro Deceng Village Pangkajene Kepulauan District of South Sulawesi Province. Torani, 19(3), 160-165. (in Indonesian)

36. Tang S.J., Liu Z.Z., Tang W.Q., Yang J.Q. 2009. A simple method for isolation of microsatellites from the mudskipper (Boleophthalmus pectinirostris), without constructing a genomic library. Conservation Genetics, 10, 1957-1959.

37. Yang K.Y., Lee S.Y., Williams G.A. 2003. Selective feeding by the mudskipper (Boleophthalmus pectinirostris) on the microalgal assemblage of a tropical mudflat. Marine Biology, 134(2), 245-256. 